\title{
Presenting Self: A Celebrification in Online
}

\section{Video Sharing}

\author{
Nungki Heriyati \\ English Department \\ Universitas Komputer Indonesia \\ Bandung, Indonesia \\ nungki.heriyati@email.unikom.ac.id
}

\begin{abstract}
The paper aimed to explore the construction of the so-called self-celebrification in online video sharing. Vloggers can be famous by sharing their videos in digital platform without having to be an expert. Moreover, they can simply share their lifestyles and daily activity. Subscribers, viewers, and comment become the indication of their stardom. The phenomenon is triggered by the changes in the entertainment consumption from broadcast to online media. As one of the most popular digital platforms, YouTube is one off the most-used video sharing platform. The usage of qualitative method in the study combines interview and close analysis using habitus theory by Bourdieu. The examination of many YouTube video sharing reveals that YouTubers stimulate certain identity related to their capital and habitus. The construction of self also shows a crisscrossing between public and private. The intersection enables vloggers to create intimacy; however, it can as well create a tension between YouTubers and their fans. The YouTubers may make a boundary for certain things for their privacy, which opposes the desire of their fans to know more about their idols.
\end{abstract}

Keywords-Capital, Celebrification, Habitus, Self, YouTube.

\section{INTRODUCTION}

Self celebrification is a term used to explain the transformation of ordinary people into celebrity [1]. Aagaard argues that celebrity is fabricated image circulated in the media that become part of gossip, public opinion, and idol [2]. The development of Internet as well as social media gives unprecedented changed to be a celebrity. Ordinary people can be a celebrity not by taking a series of casting but using online sharing platform. The phenomenon of vloggers or video blogger is triggered by the video sharing platform through which an amateur video footage can share their work. Amateur means that the creator is not professionally paid for producing the content. YouTube as the second most popular video sharing give medium of them to share their video and get recognition from their work. YouTube enables their video to be viewed by a lot of people and went viral since approximately 1.8 billion people were register to the site [3]. Dogtiev adds there are 149 million viewers in a month or about 30 million daily. Hence more than 300 hours of video uploaded to YouTube per minute. Not only serves a medium to express themselves, YouTube gives a financial benefit for them as well as the chance to be famous. In the digital age, person can view other person at a distance without having to know each other before hand. Hence, the number of viewers worldwide facilitates the YouTubers to gain recognition for their work either as vloggers, influencers, or content video writers. The phenomenon changes the way to be celebrity. Instead of take part in series of casting or contest, YouTubers only need to upload their video. However, they have to make sure that their video is watched by a lot of viewers. In other words, the content should be interesting to be watched. Besides, the indication that the viewers like the video is the number of the subscribers. The subscribers show loyal viewers who want to get update information or being notified of the newest upload video from the channel that they follow. The sharp increase of video upload in YouTube makes content video makers have to compete to make sure that their work is widely watched and liked by viewers. In fact, YouTubers especially vloggers is like a self- marketing activity. They have to present themselves in certain ways to attract the public attention and gain popularity.

There have been numerous researchers who tried to examine YouTube. Wattenhofer, Wafenhofer, and Zhu [4] analyzed the measurement of popularity in YouTube by examining subscription graph, comment graph and video content corpus. He found that YouTube has deviated traditional online social interaction since the video content markers do not necessarily becomes the follower of its subscribers. Hence, it detached homophily or likeness in term of friendship, culture, and so on as one of the basis of someone becomes other followers. In terms of presenting self, Simonsen [5], Santoso, and Berryman have tried to examine it. They focused on different aspect. Simonsen has tried to examine the identity formation in YouTube. It explores the way people present themselves and being evaluated by the audience. Santoso [6] analyzes local identity in social media which focuses on its transformation when such identity is presented online. In other words, he examines the tension between local and global. With an attempt to show that successful vloggers do not necessarily to present the positive documentation only Berryman showed that negative affect can also strengthen the intimacy between video content markers and its subscribers. Meanwhile, a 
study by Aagaard and Centeno [7] examine the concept of celebrification as a means to transform an ordinary people to spotlight and get attention.

Nevertheless, the researchers above did not analyze the importance of capital in the construction of self-presentation of ordinary people to become a celebrity or known as celebrification. The phenomenon raises a question on how the YouTubers construct the means that they use to present themselves. The study also entails the tension that occurs between private and public in relation to maintain their own privacy and create a good connection to their fans. Drawing from qualitative research using interview and Bourdieu's identity construction framework, the study entitled Presenting Self: Self Celebrification in YouTube is conducted to fill the gap from the previous research as mentioned above.

\section{METHOD}

The Paper uses qualitative research comprises two things, the first, deep interview. Interview is used to gather information from the YouTubers and viewers in order to understand the point of view of the subject that is being examined. The interview is conducted using semi structure method which means that the reseracher has already prepared the questions but added some questions during the interview to get more information from the informant.

The second is the close examination on several famous vloggers in Indonesia. Vloggers stands for Video blogger. It is YouTubers who focuses on the daily life presentation including games, how to or life style, travelling and so on.

The range of the data is from the most watch video to the less viewed YouTube channels in Indonesia indicated by the number of subcribers. The range of data is intended to show the comparison from the most popular to the less one in which shows how self is being presented. Hence, it also attempts to examine the capital that is used to make themselves stands out from other vloggers.

In order to examine the construction of identity, Bourdieu's concept on field, habitus, legitimation, doxa and heterodoxy are used. However, before explaining those concepts, the definition of identity will be explained first. Identity is the way someone identified themselves related to the name, race, gender, status, class, or nationality. Identity is not a fix entity but it is always in a process. It triggers someone to negotiate their perception, disposition, or preferences in order to be acknowledged by the society at large or certain group.

The identity shows how actors interact in the social field. Bourdieu [8] put forwards the concept of field to explain the space where people interact each other in which creates a competition to get access to the power. YouTube can also be considered as field of social interaction since it provides a space for people to interact.

Furthermore, the way actors set their positions in the social interaction creates a habitus. Habitus cannot be constructed easily because it is inculcated since they were born. It determines the way people react or respond to certain situation.
In the social field, there are series of dominant views that determine certain rules and become the measurement of some values among others good or bad, esthetic or unaesthetic, and high or low. Bourdieu [9] called it as doxa. As oppose to dominant view, Bourdieu introduced heterodoxy. It is like a resistant act to the cultural mainstream.

To set a position in the social field, people need capital. It refers to the resources owned by someone including economic, social, cultural, and symbolic. Economic capital is related to the distinction between those who have financial resources and who have not. Social capital is a social relation in the society. Meanwhile, cultural capital is related to knowledge and capability. Then, symbolic capital related to a prestige and status of the actors.

Having capital does not mean that a person can gain power automatically. Instead an actors need to exercise the capital that is owned by them to get legitimation. Bordieu divides legitimation into three types. First is legitimate taste. The legitimate taste is considered highbrow and it is determined by certain group of people who have a privilege. Second is middle-brow taste, it brings major and minor taste together. Third is popular taste. It is considered low-brow and trivial; however, it exceeds in number.

\section{RESULTS AND DISCUSSION}

\section{A. YouTube as Social Field}

Founded by three PayPal employees, Chad Hurley, Steve Chen, and Jawed Karim in 2005, YouTube gains its unprecedented popularity. The ideas of building the platform is originated by the difficulty in sharing a party video via email. A year later, the company was bought by Google for 1.65 billion dollars.

The popularity is triggered by the easy and handy way to share a video which gives an opportunity of amateur video makers to publish and share their work. They can upload as much as they want. In turn, the large amounts of video sharing change the way people communicate, learn, and entertain themselves. Instead of doing it conventionally, people can communicate or learn by watching video on YouTube.

YouTube is considered to replace conventional television. According to Smith "In 2015, 18-49 year-old spent $4 \%$ less time watching television while time on YouTube went up 74\%" [10]. Not only gives a chance for viewers to watch video based on their own preferences without have to stick to the broadcast schedule, but the viewers also have a power to pause and re-watch the video that they like to see. It becomes an enticing appeal of YouTube compare to Television.

Another appeal of YouTube as video sharing platform is the possibility for ordinary people to become famous. Scheepp and Schepp [11] argue that 99 percent of famous YouTubers is ordinary people. To be famous, they simply upload their video and make sure that they get many viewers. The content can be about education, life style, comedy, auto and vehicles, entertainment, news, politic, music, and 
traveling, to name a few. The possibility to be famous and get financial benefit triggers people to upload their video.

Furthermore, uploading video to YouTube is not hard. The platform provides an easy way to share video. The YouTubers simply can upload anything to their channels. To engage in YouTube, users only need to have an account and sign in. Creating an account means that users have to fill some personal information and confirm the registration in the email. Since Goggle owns YouTube, Users can use the same account to sign in. After becoming a member, users have channel and can share their video by clicking the upload button.

Users can also customize their account by filling in the description of the channel, and creating tags. In addition, they can choose whether viewers can give comment to the video or not. The description and tags are information about the content of the channels which is important for the viewers. However, YouTubers can change their profile later on. Thus, it is so flexible and easy.

Schepp and Schepp note basic criteria to be a YouTube partner, first the video that is uploaded must be an original work. Second, there is a legal permission to use the video. Third, uploading the video must be done regularly. The first and second criteria are a way to avoid the infringement of copyright. The third criterion is an indication that the channel is an active user. By uploading video regularly, YouTubers can maintain a loyal community because viewers tend to see the most recent video.

The elaboration on YouTube above implies that YouTube can be regarded as a new innovation to the conventional television by its User-generated content (UGC). Thus, it serves as a heterodoxy that defies the conventional way to communicate, learn, and entertain themselves. On one hand, UGC liberates its users to consume the video whenever they want. On the other hand, it enables users to be a producer for their own video. Even so, YouTube also regulates certain rules that must be followed by its users. YouTube censors a video containing among others abuse, drug promotion, violence, infringement of copy right, and controversial subject. Hence video that is not advertisementfriendly content such as monetization is also banned. Viewers can also report video that contains controversial issues or insult certain groups.

Furthermore, the interaction between viewers and YouTubers as well as interaction among YouTubers shows a new social field in digital era. As a social field, there are agents that perform the cultural practices and symbolic exchange. The agents might compete to gain power; thus they must perform themselves to be stand out.

\section{B. The Construction of Self}

As a social field, in YouTuber, there are interactions among the users. They also act as agents that have to make a strategy to be accepted as YouTubers. In YouTube, the cultural practices seem to be more dynamic and flexible because instead of being determined by cultural mainstream, it is based on popularity and trend. YouTube does not depend on legitimate taste determined by certain high profile or important person in the society; rather it is controlled by folks taste.
Since the legitimation of becoming a YouTubers is based on the popularity indicated by subscribers, viewers, likes and comments, gaining visibility becomes important things to do. Additionally, it is also the measurement to get financial benefits. In other words, visibility is equal to power since those who gain more visibility are regarded more popular compare to the other channels. It determines the social class among YouTubers.

The visibility will promote the channel popularity because YouTube gives information on the number of viewer, likes, and subscribers. The more viewer, the more it entices another users to watch and share it in another platform. The more it share and watch, the more it is likely to be a viral video. Hence, the popularity also makes a company wants to advertise in it.

However, the vast amount of video sharing in YouTube makes it difficult to gain the visibility. In order to get loyal followers which means increase visibility, the YouTubers often ask the viewers to subscribe their channel, watch other videos in their channel, and give like or comment in the beginning or the ending of the video. Besides put the persuasion in the video, hashtag is also one of the strategies to raise the visibility. YouTube will list video related to the keywords typed by the users.

The dependence on public taste indicates that the power in this field is dispersed and hard to be perceived. There is no one representative power that is visible. In YouTube case, consumption is a power that equal to economy and political power. YouTubers have power to choose video that they want to share and select who can view the video. Similarly, viewers are free to choose the content that they want to watch and choose to subscribe the channel they like. Choosing the channel is based on the preferences on what kind of video that meet viewers need.

Also, the YouTubers must negotiate their disposition by exercising their capital. Capital owned by YouTubers indeed gives a substantial impact to the visibility. YouTubers present themselves based on their capital.

The cultural capital or their ability is one of the considerations to choose the field that they want to enter i.e. beauty vloggers, traveler vloggers, or horror vloggers. The way they present their cultural capital is shown for example by Risa Saraswati [12] who has an ability to speak to the ghost. Her channels JurnalRisa accumulate 632 thousand subscribers. Another YouTubers, Raditya Dika [13] who is also known as comic (a person who does standup comedy) can gather 4.5 million subscribers. Then, Fathia Izzani $[14,15]$ with her ability to speak in 21 accents gains 540 thousand subscribers, her video went viral by gaining 9.9 million viewers.

Another important cultural capital is tech-savvy vloggers. The ability makes them able to edit their own video. They can also add an interesting content and cut some unimportant or private chat in their video. In fact, the content video of vloggers is usually about daily life. The interview from informant [16] shows that the YouTube viewers believed that vloggers present themselves naturally as they are in the real life. However, the editing process might cut out some information or situation that the vloggers do not want to share to the viewers. 
Besides, the cultural capital, economic capital affects the presentation of the video. The examination on the most popular video and less one shows the differences in the video quality. The most watched video tends to have a good quality video and audio compare to the less viewed. It is caused by the financial resources that they have. Furthermore, financial resources enable them to have a team that help them to make a better video content, take in charge of camera, and edit it. Some amateurs and beginners are having difficulties to compete with them since they are not provided with high tech equipment. By having a good quality video, they are more likely to gain more viewers as a result they will gain more economic capital.

Furthermore, their popularity gives also a symbolic capital. Since they are popular, their name gives certain status and prestige that can be exchanged to gain more benefit. A company is more likely to advertise in the popular channels.

In other words, the economic system and hierarchy also occupy in this field. Class determines on how an actor act and how other perceived them. However, the field is not deterministic and more dynamic; the system gives an agency for amateur to raise their class by creating a captivating content that make it viral. Thus, innovation and creativity can be a means to raise their status which in turn gives financial benefit. Awkarin [17] is one of YouTubers that went viral for her heartbroken video. Started as a selebgram, she then made a video content in YouTube. Despite the controversy of the free life style presented in her video, she gathered 807 thousand subscribers.

Social capital is also important for YouTubers in terms of gaining viewers. Friendship can be used to accumulate viewers by asking them to watch and share to other friends. If you have ten friends that share the video to ten other friends, the number of viewers will increase significantly and if it continues it will be a viral video.

Some YouTubers can invite famous person that they know to their channels to raise the viewers. Tasya Farasya [18], a beauty vlog who has 665 thousands subscribers, for example, invites Nagita Slavina and Titi Kamal to her channel. Both are famous actress which can impose more viewers to watch her channels. Thus, both actresses serve as capital social for Tasya Farasya.

YouTubers can also make a collaboration video to accumulate fans. Ria Ricis [19] and Atta Halilintar [20] sometimes do a join video content, even though the number of their subscribers is quite fantastic. Ria Ricis has 5.1 million subscribers, while Atta Halilintar has 4.2 million subscribers. By making collaboration they can gain more viewers since both fans watch the video. Both are vloggers that focus on presenting their daily life and presenting a cheerful and active young adult. Playing with squishy and LOL surprise (both are toys) are one of the video content of Ria Ricis. Sometimes, Atta Halilintar participated in the video. Their target market is teenagers which is one of the reasons of gaining a lot of subscribers. Statista.com notes that viewers mostly teenagers and young adult.

Another method in using the social capital is to be promoted a YouTubers that is more popular. Beginners can collaborate with famous YouTubers while promoting their own channels. By doing so, their channels can get recognition from the viewers.
The elaboration above shows that YouTubers construct themselves based on their capital. It also determines the content that they want to present and the way they present it. Although the economic system also influences how YouTube is structured, the actors can negotiate their position to gain power.

\section{The Tension between Private and Public}

The interesting phenomenon occurred in YouTube as a social field is the tendency to perform daily life. As mentioned earlier, Vloggers tend to present their daily life. Paradoxically, private becomes public.

Vloggers have turned their private life into public consumption by making it into playful activity. The informant told that the reason why they watch a private life of someone else is to compare their life to someone else. They are curious to know whether famous person do the same foolish things that they usually do.

According to Nardi, as cited by Lange [21] the feeling of connection is important for the viewers. A private video transmits closeness and familiarity which in turn make the viewers feel that they participate in the vloggers life. It explains why people like to watch trivial video that does not contain much education in it.

However, making private public is not without danger. Private is something that is hidden, in contrast public is something that is open. There is a tendency for people to keep private life for themselves. However, since the famous vloggers life is exposed to a great extent, some fans might have an expectation to know all. Moreover, they want to determine what things that must be done by their idolized person.

In the case of Atta Halilintar for example, the fans give negative comment when Atta had a relationship to a girl that they did not approve. They even bullied her for which Atta disabled the comment. The phenomenon shows the tension between public and private. The fans want to determine their idol life as if it is their own.

On the other hand, vloggers must still maintain a good relationship with their viewers or else they might lose their subscribers. Thus they have to make a strategy to keep a private life but maintain their fans' intimacy. In fact, YouTube provides features that maintain privacy. YouTubers can select to whom their video is shared. Some videos can be viewed by certain people while the others go public.

Editing process is also one of the ways to make a selection which part that should be made public and which part that needs to be erased.

In sum, YouTubers must make a strategy to negotiate their position and disposition in social media. It includes the manipulation of technical features provided in YouTube. The strategy is used to keep their own privacy while maintaining intimacy with their fans.

\section{CONCLUSION}

YouTube changes the way we communicate, learn, and behave. It is a social filed in a digital era. As a social field, there are interaction, competition, and negotiation among its users. To gain a position they have to exercise the capital 
owned by them. As a sharing video platform, YouTube gives an opportunity for an amateur to share their work which leads them to gain popularity. Since vloggers mainly tells about private life, it creates a tension between public and private.

\section{ACKNOWLEDGMENT}

We gratefully acknowledge financial support from UNIKOM

\section{REFERENCES}

[1] Berryman R, Misha K. Crying on YouTube: Vlogs, Self-exposure and the productivity of nagative affect. 2018. [cited 2018 Agust 10] vol 24(1) 85-98. Avaliable from: http://sagepub.com/home/com DOI: $10.177 / 1354856517736981$

[2] Aagaard K E. Performed Realities and Intertextualities: The Comodification of Everyday Life and Celebrification of Everyday People in Modern Television and Digital Cultures. Major Research Paper [Doctoral dissertation], Canada: York University. [cited 2018 $\begin{array}{llll}\text { Agust } 18] \text {. Avaliable } & \end{array}$ http://digital.library.ryerson.ca/.../Performed realities and intertextua lities the commodif.

[3] Dogtiev A. YouTube Revenue and Usage Statistics (2018). 2018 June 1 [cited 2018 August 12] Avaliable from: https://businessofapps.com

[4] Wattenhofer M, Wattenhofer R, Zhu Z. The YouTube Social Network. InSixth International AAAI Conference on Weblogs and Social Media 2012 May 20. [cited 2018 August 10] Avaliable from: https://research.google.com/pubs/archive/37738.pdf

[5] Simonsen T.M. Indentity-Formation on YouTube: Investigating Audiovisual Presentation of the Self, Denmark: Aalborg Universitet, 2012

[6] Santoso E.. Identitas Lokal dalam Media Sosial: Studi tentang habitus, Modal, ranah, dan Praktik Kebahasaan Orang Banyumas di Media Sosial Depok: Universitas Indonesia, Juni 2015

[7] Centeno DD. Celebrification in Philippine Politics: Exploring the Relationship Between Celebrity Endorser's Parasociability and the Public's Voting Behavior. Social Science Diliman. 2010 Nov 5;6(1).
[8] Bourdieu P. Arena Produksi kultural: sebuah kajian sosiologi budaya, Bantul: Kreasi wacana, 2012

[9] Bourdieu P. Distinction: A Social Critique of the Judgement of Taste. Cambridge: Harvard University Press, 2002

[10] Smith K. 39 Facinating and Incredible YouTube Stasitics [Internet] Brighton: Branwatch. 2018 April 12 [cited 2018 August 12] Avaliable from: http:// www.brandwatch.com/blog/39-YouTube-Stat

[11] Scheep B. and Schepp D. How to Make Money with YouTube: Earn Cash, Market, Reach Your Customers, and Grow Your Business on the World's Most Popular-Sharing Site, New York: McGraw Hill, 2009

[12] JurnalRisa. Home [YouTube Channel] 2017 August 29. Avaliable from: https://www.youtube.com/channel/UCKFC1LYWw1fbe9LNfm2vEP g

[13] Fathia Izzani. Home [YouTube Channel] 2011 May 30. Avaliable from: https://www.youtube.com/user/kittendust

[14] Fathia Izzani. 21 Accents [YouTube] 2013 August 30. Avaliable from: https://www.youtube.com/watch?v=VAWt0OJ65Bc

[15] Raditya Dika Official YouTube Channel. Home [YouTube Channel] 2007 June 28. Avaliable from: https://youtube.com/user/radityadika/featured.

[16] Andriyani W. How YouTubers present themselves. [oral communication, 2018 June 25]

[17] Karin Novilda. Home [YouTube Channel] 2014 January 26. Avaliable from: https://www.youtube.com/channel/UCDs47Uey2EitsrMaPxDXXkw

[18] Tasya Faraya. Home [YouTube Channels] 2016 October 3. https://www.youtube.com/channel/UCJCSL8IJD4dsnunRrmrT1Q/fea tured

[19] Ria Ricis. Home [YouTube Channel] 2016 January 15. Avaliable from:

https://www.youtube.com/channel/UC4tS4Q_Cno5JVcIUXxQOOpA /featured

[20] Atta Halilintar. Home [YouTube Channel] 2014 January 26. Avaliable from: https://www.youtube.com/channel/UCaKLg1ELiX0zTJ6Je3c5esA

[21] Lange P.G. Publicly Private and Privately Public: Social Networking on YouTube DOI: 10.1111/j.1083-6101.2007.00400.x 